ISSN 0258-7122

Bangladesh J. Agril. Res. 39(2): 283-291, June 2014

\title{
COMBINING ABILITY STUDY IN WATERLOGGED TOLERANT MAIZE (Zea mays L.)
}

\author{
M. N. Amin ${ }^{1}$, M. AmiruZZAman' ${ }^{2}$ A. Ahmed ${ }^{3}$ AND M. R. Ali ${ }^{4}$
}

\begin{abstract}
Combining ability was studied for kernel yield and yield components in a $8 \times 8$ diallel cross of waterlogged tolerant maize. Significant general and specific combining ability variances were observed for all the characters studied. Additive genetic variance was preponderant in plant height, ear height, ear length, ear diameter, and kernel weight and non-additive gene action was involved in days to silking, number of kernels per ear and kernel yield. The parental lines E-31 and E-79 were found to be the best general combiners for yield. The good combining parents for different traits could be used in hybridization to improve yield and other desirable traits as donor parents for the accumulation of favourable genes. The cross combinations, E $31 \times$ E 40, E $31 \times \mathrm{E}$ 64, E 31× E 79, E 38× E 40, E 58× E 79, E 63× E 79, E $64 \times$ E 79 showing significant and positive sca effects can be used for commercial hybrid variety development after verifying them at different locations.
\end{abstract}

Keywords: Heterosis, combining ability, grain yield, maize.

\section{Introduction}

Maize (Zea mays L.) is cultivated in diverse agro climatic zones extending from the subtropical to the cooler temperate regions. Therefore, the crop remains inevitably open to varied types of biotic as well as abiotic stress conditions. Among the various abiotic conditions, excess soil moisture (ESM) stress caused by temporary water logging due to heavy rain or high ground water table or heavy soil texture is one of the most important constraints for maize cultivation in Bangladesh. In South East Asia, about $15 \%$ of total maize growing area is affected by floods and water logging (Rathore et al., 1997). The maize crop suffers badly whenever it encounters temporary ESM conditions during the monsoon season or grown in poorly drained converted paddy fields after the rainy season rice crop .

Maize is generally considered to be a flood tolerant species due to its ability to produce early adventitious roots and morphological adaptability (arenchyma formation) during excess soil moisture condition (Drew et al., 1979 and Fausey et al.,1985). In monsoon sowing, it is difficult to avoid water logging at one or

${ }^{1}$ Scientific Officer, Plant Breeding Division, Bangladesh Agricultural Research Institute (BARI), Gazipur, ${ }^{2}$ Principal Scientific Officer, Plant Breeding Division, BARI, Gazipur, ${ }^{3}$ Scientific Officer, Plant Breeding Division, BARI, Gazipur, ${ }^{4}$ Chief Scientific Officer, Plant Breeding Division, BARI, Gazipur, Bangladesh. 
other stage of the crop growth due to erratic rains. Further, low lying area faces severe water logging problem during the winter season. The tolerance of maize genotypes towards this particular type of stress varies considerably and is higly influenced by the degree of stress and the genotype of the plant (Torbert et al., 1993). Hence, there is a need to screen the collected germplasm with adaptive potential to perform well under temporary water logging conditions and identify the morphological and physiological traits conferring resistance to excess soil moisture and incorporate these traits in well adapted genotypes to end up with promising materials. Combining ability analysis is useful to assess the potential inbred lines. It also helps in identifying the nature of gene action involved in various quantitative characters. This information is helpful to plant breeders for formulating hybrid development programmes. Therefore, the present investigation was undertaken to isolate desirable inbred lines and better combining parents for development of suitable waterlog tolerant maize hybrids.

\section{Materials and Method}

Eight medium waterlogged tolerant maize inbred lines were mated in a $8 \times 8$ diallel fashion excluding the reciprocals during the rabi season in 2011-12. The resulting $28 \mathrm{~F}_{1} \mathrm{~s}$ and their parents were evaluated along with two checks (BARI Hybrid Maize-9 and 900M Gold) in a alpha lattice design with three replications at the Bangladesh Agricultural Research Institute, Gazipur in the rabi season of 2012-2013. Each plot consisted of single row of 5m long. The spacing between rows was $60 \mathrm{~cm}$ and plant to plant was $20 \mathrm{~cm}$. One plant per hill was maintained after proper thinning. Observations were recorded on ten randomly selected plants from each plot for plant height, ear height, ear length, ear diameter, number of kernels per ear, and 1000-kernel weight. Days to silking and kernel yield were recorded on whole plot basis and the yield was converted to tons per hectare.

Data were analyzed for variance study. General combining ability (GCA) and specific combining ability (SCA) were estimated following Model I, Method II of Griffing (1956).

\section{Results and Discussion}

The mean performances of the 28 crosses along with the checks are presented in Table 1 . The genotypes differed significantly for all the characters, except ear length and diameter and kernel weight, indicating sufficient genetic variability present in these traits. Mean squares due to genotypes (diallel hybrids) were highly significant for all the traits except 1000-kernel weight which indicated the presence of adequate amount of variability in the materials. Further, analysis of variance for combining ability showed that the estimates of mean squares due to GCA and SCA were highly significant for all the characters except kernel weight 
for GCA (Table 2). This indicated the importance of both additive and nonadditive components of genetic variances in controlling these traits. Debnath and Sarker (1990) and Derera et al. (2007) reported similar results for yield and yield components in maize. The higher magnitudes of GCA variances were found for plant height, ear height, ear length, ear diameter, which indicated the predominance of additive gene action. According to Dhillon and Singh (1976), GCA was more important than SCA for the inheritance of days to 50 per cent silking, grain moisture, plant height, ear height, ear length, ear circumference and kernel row number but not for grain yield. Murthy et al. (1981) observed predominance of additive gene action for days to silking and non-additive gene action for grain yield per plant. Das and Islam (1993) also reported predominance of non additive gene action for grain yield. Combining ability studies revealed higher SCA variance than GCA variance and thus the GCA to SCA variance ratio was less than the unity indicating the predominance of non additive gene action. These results confirmed the findings of Singh et al. (1983) and Paul and Duara (1991).

Table 1. Mean performances of waterlogged tolerant hybrids obtained from $8 \times 8$ diallel cross evaluated at Joydebpur during rabi 2012-13.

\begin{tabular}{|c|c|c|c|c|c|c|c|c|c|}
\hline $\begin{array}{l}\text { Sl. } \\
\text { No. }\end{array}$ & Cross & $\begin{array}{c}\text { Days to } \\
\text { silking }\end{array}$ & $\begin{array}{l}\text { Plant } \\
\text { ht. } \\
(\mathrm{cm})\end{array}$ & $\begin{array}{c}\text { Ear ht. } \\
(\mathrm{cm})\end{array}$ & $\begin{array}{c}\text { Ear } \\
\text { length } \\
(\mathrm{cm})\end{array}$ & $\begin{array}{l}\text { Ear } \\
\text { dia. } \\
(\mathrm{cm})\end{array}$ & $\begin{array}{l}\text { Kernel/ } \\
\text { ear (no.) }\end{array}$ & $\begin{array}{l}1000- \\
\text { kernel } \\
\text { wt (g) }\end{array}$ & $\begin{array}{l}\text { Grain } \\
\text { yield } \\
\text { (t/ha) }\end{array}$ \\
\hline 1. & E $31 \times$ E 38 & 89 & 158 & 63 & 15 & 4.3 & 310 & 355 & 7.0 \\
\hline 2. & E $31 \times$ E 40 & 89 & 136 & 71 & 15 & 4.6 & 358 & 337 & 7.6 \\
\hline 3. & E $31 \times$ E 58 & 88 & 148 & 61 & 12 & 4.5 & 342 & 351 & 6.7 \\
\hline 4. & E $31 \times$ E 61 & 88 & 152 & 70 & 14 & 4.5 & 343 & 337 & 6.4 \\
\hline 5. & E $31 \times$ E 63 & 89 & 181 & 72 & 17 & 4.8 & 378 & 394 & 7.3 \\
\hline 6. & E $31 \times$ E 64 & 89 & 164 & 73 & 14 & 4.5 & 323 & 366 & 8.1 \\
\hline 7. & E $31 \times$ E 79 & 91 & 150 & 72 & 17 & 4.4 & 502 & 400 & 9.0 \\
\hline 8. & E $38 \times$ E 40 & 93 & 142 & 76 & 13 & 4.0 & 259 & 356 & 7.0 \\
\hline 9. & E $38 \times$ E 61 & 87 & 123 & 52 & 12 & 4.2 & 311 & 410 & 5.0 \\
\hline 10. & E $38 \times$ E 58 & 87 & 145 & 44 & 12 & 4.2 & 280 & 389 & 6.0 \\
\hline 11. & E $38 \times$ E 63 & 88 & 140 & 54 & 13 & 4.2 & 306 & 370 & 5.5 \\
\hline 12. & E $38 \times$ E 64 & 90 & 165 & 54 & 12 & 4.4 & 329 & 267 & 5.3 \\
\hline 13. & E $38 \times$ E 79 & 91 & 134 & 53 & 15 & 4.0 & 391 & 331 & 5.8 \\
\hline 14. & E $40 \times$ E 58 & 92 & 151 & 60 & 10 & 4.3 & 256 & 393 & 4.6 \\
\hline 15. & E $40 \times$ E 61 & 94 & 157 & 76 & 11 & 4.4 & 238 & 353 & 5.6 \\
\hline 16. & E $40 \times$ E 63 & 94 & 144 & 78 & 13 & 4.1 & 228 & 324 & 5.9 \\
\hline 17. & E $40 \times$ E 64 & 89 & 160 & 65 & 11 & 4.6 & 238 & 348 & 4.9 \\
\hline
\end{tabular}


Table 1. Cont'd.

\begin{tabular}{|c|c|c|c|c|c|c|c|c|c|}
\hline $\begin{array}{l}\text { Sl. } \\
\text { No. }\end{array}$ & Cross & $\begin{array}{l}\text { Days to } \\
\text { silking }\end{array}$ & $\begin{array}{l}\text { Plant } \\
\text { ht. } \\
(\mathrm{cm})\end{array}$ & $\begin{array}{c}\text { Ear ht. } \\
(\mathrm{cm})\end{array}$ & $\begin{array}{c}\text { Ear } \\
\text { length } \\
(\mathrm{cm})\end{array}$ & $\begin{array}{l}\text { Ear } \\
\text { dia. } \\
(\mathrm{cm})\end{array}$ & $\begin{array}{c}\text { Kernel/ } \\
\text { ear (no.) }\end{array}$ & $\begin{array}{l}1000- \\
\text { kernel } \\
\text { wt }(\mathrm{g})\end{array}$ & $\begin{array}{l}\text { Grain } \\
\text { yield } \\
\text { (t/ha) }\end{array}$ \\
\hline 18. & E $40 \times$ E 79 & 94 & 111 & 63 & 12 & 4.2 & 311 & 370 & 5.3 \\
\hline 19. & Е $58 \times$ E 61 & 89 & 84 & 48 & 10 & 4.4 & 293 & 370 & 5.2 \\
\hline 20. & Е $58 \times$ E 63 & 89 & 112 & 49 & 11 & 4.5 & 320 & 346 & 5.9 \\
\hline 21. & E $58 \times$ E 64 & 88 & 147 & 47 & 11 & 4.4 & 306 & 312 & 5.4 \\
\hline 22 & E $58 \times$ E 79 & 88 & 118 & 54 & 13 & 4.1 & 376 & 477 & 7.4 \\
\hline 23. & E $61 \times$ E 63 & 90 & 112 & 45 & 12 & 4.2 & 287 & 366 & 5.5 \\
\hline 24. & E $61 \times$ E 64 & 93 & 167 & 44 & 12 & 4.2 & 320 & 276 & 5.5 \\
\hline 25. & E $61 \times$ E 79 & 89 & 129 & 66 & 13 & 4.2 & 374 & 352 & 6.2 \\
\hline 26. & E $63 \times$ E 64 & 95 & 179 & 52 & 13 & 4.1 & 294 & 320 & 4.4 \\
\hline 27. & E $63 \times$ E 79 & 91 & 163 & 71 & 15 & 4.1 & 367 & 353 & 8.2 \\
\hline 28. & E $64 \times$ E 79 & 91 & 158 & 66 & 14 & 3.8 & 390 & 355 & 7.3 \\
\hline 29. & 900m Gold & 99 & 212 & 115 & 18 & 5.1 & 390 & 300 & 9.9 \\
\hline \multirow[t]{5}{*}{30.} & BHM 9 & 98 & 215 & 115 & 19 & 5.0 & 395 & 332 & 9 \\
\hline & Mean & 91 & 135 & 56 & 13 & 4.3 & 297 & 344 & 5.61 \\
\hline & F-test & $* *$ & $* *$ & $* *$ & - & - & $* *$ & - & $* *$ \\
\hline & $\mathrm{CV}(\%)$ & 1.62 & 10.2 & 16.3 & 12.9 & 8.4 & 17.80 & 20.93 & 18.69 \\
\hline & $\operatorname{LSD}(5 \%)$ & 2.4 & 22.4 & 15.1 & 2.5 & 0.6 & 86.2 & 117.4 & 1.7 \\
\hline
\end{tabular}

$*$, ** indicated at $5 \%$ and $1 \%$ level of significance.

Table 2. Mean squares due to general and specific combining abilities (GCA and SCA) in $8 \times 8$ diallel cross of waterlogged tolerant maize.

\begin{tabular}{|c|c|c|c|c|c|c|c|c|c|}
\hline \multirow[b]{2}{*}{$\begin{array}{c}\text { Sources of } \\
\text { variation }\end{array}$} & \multirow[b]{2}{*}{ df } & \multicolumn{8}{|c|}{ Mean of squares } \\
\hline & & \begin{tabular}{|c|} 
Days \\
to \\
silking
\end{tabular} & $\begin{array}{l}\text { Plant } \\
\text { height } \\
(\mathrm{cm})\end{array}$ & $\begin{array}{c}\text { Ear } \\
\text { height } \\
(\mathrm{cm})\end{array}$ & $\begin{array}{l}\text { Ear } \\
\text { length } \\
(\mathrm{cm})\end{array}$ & $\begin{array}{c}\text { Ear } \\
\text { diam. } \\
(\mathrm{cm})\end{array}$ & $\begin{array}{c}\text { Kernel/ } \\
\text { ear } \\
\text { (no.) }\end{array}$ & $\begin{array}{l}1000- \\
\text { kernel } \\
\text { wt }(\mathrm{g})\end{array}$ & $\begin{array}{l}\text { Grain } \\
\text { yield } \\
(\mathrm{t} / \mathrm{ha})\end{array}$ \\
\hline Genotypes & 35 & $44 * *$ & $2229 * *$ & $556.5 * *$ & $15.4 * *$ & $0.83 * *$ & $7268 * *$ & 6489 & $7.25 * *$ \\
\hline GCA & 7 & $25^{* * *}$ & $4847 * *$ & $1114^{* *}$ & $18.3 * *$ & $1.13 * *$ & $14982 * *$ & 9813 & $6.82 * *$ \\
\hline $\mathrm{SCA}$ & 28 & $49 * *$ & $1574 * *$ & $417 * *$ & $14.7 * *$ & $0.74 * *$ & $25005^{* *}$ & $5658 *$ & $7.36^{* *}$ \\
\hline Error & 70 & 2 & 189 & 85 & 2.34 & 0.12 & 12476 & 5193 & 1.10 \\
\hline $\begin{array}{l}\text { GCA: } \\
\text { SCA }\end{array}$ & & 0.51 & 3.08 & 2.67 & 1.25 & 1.51 & 0.60 & 1.7 & 0.93 \\
\hline
\end{tabular}

$*, * *$ indicated at $5 \%$ and $1 \%$ level of significance 


\section{General combining ability (gca) effects}

The gca effects of the parents for different characters are presented in Table 3. A wide range of variability for gca effects of different characters was observed among the parents. The parental lines E-31 and E-58 had significant negative gca effects for days to silking; E-61 had both for plant and ear height, indicating early maturity, shorter plants and low ear placement of the parents, respectively (Table 3). Debnath and Sarker (1989) and Hussain et al. (2003) observed good combiners for short plant type in their studies. The parent E-58 showed significant negative gca effect for days to silking. The inbred lines which exhibited good general combining ability for at least one character can be used for development of early maturity and high grain yield.

Among the parents, E-31 had desirable significant gca effect for ear length; E-31, and E-79 for number of kernels per ear. The parental lines with the significant and the highest value of gca effect for kernel yield was E-31 (0.84) followed by E-79 (0.68). The lowest gca value (-0.36) was observed in E-64 for this trait. Significant positive gca effect of the parental lines for grain yield was reported by Hussain et al. (2003). None of the parents showed good general combining ability for all the yield components. The results of the gca effect suggested that the parents E-31and E-79 were good combiner for yield. These two parents were also good combiners for major yield components like ear length and kernel number. Parents E-31, E-58, and E-38 could be used for exploiting earliness; E-61 for short plant stature, and E-31 for longer ears and higher number of kernels. These parents could be used in hybridization to improve yield as well as other desirable traits as donor parents for the accumulation of favorable genes.

Table 3. General combining ability (gca) effects for different characters in $8 \times 8$ diallel cross of waterlog tolerant maize.

\begin{tabular}{c|c|c|c|c|c|c|c|c}
\hline Parents & $\begin{array}{c}\text { Days to } \\
\text { silking }\end{array}$ & $\begin{array}{c}\text { Plant } \\
\text { height }\end{array}$ & $\begin{array}{c}\text { Ear } \\
\text { height }\end{array}$ & $\begin{array}{c}\text { Ear } \\
\text { length }\end{array}$ & $\begin{array}{c}\text { Ear } \\
\text { dia. }\end{array}$ & $\begin{array}{c}\text { Kernels } \\
\text { lear }\end{array}$ & $\begin{array}{c}1000- \\
\text { kernel wt }\end{array}$ & $\begin{array}{c}\text { Grain } \\
\text { yield }\end{array}$ \\
\hline E - 31 & $-0.8^{*}$ & $7.1^{*}$ & $5.0^{*}$ & $1.4^{* *}$ & 0.1 & $41.4^{* *}$ & 0.5 & $0.84^{* *}$ \\
E - 38 & $-0.6^{*}$ & 0.1 & $-6.7^{* *}$ & 0.05 & $-0.3^{* *}$ & -8.4 & 3.9 & $-0.22^{*}$ \\
E - 40 & 1.3 & $6.9^{*}$ & $6.9^{* *}$ & -0.5 & 0.1 & $-40.8^{* *}$ & 2.7 & -0.17 \\
E - 58 & $-1.4^{* *}$ & $20.6^{* *}$ & $-7.9^{* *}$ & $-1.2^{* *}$ & 0.1 & -11.0 & -10.3 & $-0.33^{*}$ \\
E - 61 & -0.2 & $-9.9^{* *}$ & $-4.1^{*}$ & -0.4 & 0.1 & -13.9 & 18.7 & $-0.31^{*}$ \\
E - 63 & 0.5 & -2.7 & 3.3 & 0.4 & 0.1 & -4.7 & 7.7 & -0.11 \\
E - 64 & 0.3 & -3.1 & -2.9 & -0.3 & 0.1 & -7.3 & 15.6 & $-0.36^{*}$ \\
E - 79 & 1.0 & $22.2^{* *}$ & $6.5^{* *}$ & 0.6 & $-0.4^{* *}$ & $44.7^{* *}$ & $-38.9^{*}$ & $0.68^{* *}$ \\
\hline SE & 0.26 & 2.35 & 1.58 & 0.3 & 0.06 & 9.04 & 12.3 & 0.18 \\
LSD (5\%) & 0.60 & 5.56 & 3.74 & 0.61 & 0.14 & 21.38 & 29.1 & 0.43 \\
LSD (1\%) & 0.91 & 8.22 & 5.53 & 0.91 & 0.21 & 31.63 & 43.04 & 0.63 \\
\hline
\end{tabular}

$*, * *$ indicated at $5 \%$ and $1 \%$ level of significance 
Table 4. Specific combining ability (sca) effects for different characters in $8 \times 8$ diallel cross of waterlogged tolerant hybrids evaluated at Gazipur during 2012-13

\begin{tabular}{|c|c|c|c|c|c|c|c|c|c|}
\hline $\begin{array}{l}\text { Sl } \\
\text { No. }\end{array}$ & Cross & $\begin{array}{l}\text { Days to } \\
\text { silking }\end{array}$ & $\begin{array}{c}\text { Plant } \\
\text { height }\end{array}$ & $\begin{array}{c}\text { Ear } \\
\text { height }\end{array}$ & $\begin{array}{c}\text { Ear } \\
\text { length }\end{array}$ & $\begin{array}{l}\text { Ear } \\
\text { dia. }\end{array}$ & $\begin{array}{c}\text { Kernels/ } \\
\text { ear }\end{array}$ & $\begin{array}{c}1000- \\
\text { kernel } \\
\text { wt }\end{array}$ & $\begin{array}{l}\text { Grain } \\
\text { yield }\end{array}$ \\
\hline 1. & E $31 \times$ E 38 & -1.1 & $17.6^{*}$ & 8.2 & 1.3 & 0.3 & -20.0 & 24.1 & 0.8 \\
\hline 2. & E $31 \times$ E 40 & $-3.3 * *$ & 8.3 & 2.6 & $1.9 *$ & 0.3 & $59.9 *$ & 7.4 & $1.3 *$ \\
\hline 3. & E $31 \times$ E 58 & -2.0 & 14.0 & 7.0 & -0.7 & 0.2 & 14.4 & 2.5 & 0.6 \\
\hline 4. & E $31 \times$ E 61 & $-2.6 * *$ & $15.0 * *$ & $11.8 *$ & 1.0 & 0.2 & $18.1 * *$ & -12.4 & 0.3 \\
\hline 5. & E $31 \times$ E 63 & $-2.2 * *$ & 12.1 & 6.7 & $3.1^{*}$ & $0.4^{*}$ & 43.5 & -15.3 & 1.0 \\
\hline 6. & E $31 \times$ E 64 & $-2.7 * *$ & $41.4 * *$ & $14.3 * *$ & 0.9 & 0.2 & -8.4 & 33.4 & $2.1 * *$ \\
\hline 7. & E $31 \times$ E 79 & -1.0 & -0.5 & 3.3 & $3.2 *$ & $0.5^{*}$ & $118.3 * *$ & 59.9 & $1.9 *$ \\
\hline 8. & E $38 \times$ E 40 & 0.5 & 7.8 & $18.9 * *$ & 1.2 & 0.0 & 10.6 & 49.4 & $1.8^{*}$ \\
\hline 9. & Е $38 \times$ E 61 & $-2.5 * *$ & $26.8 * *$ & $9.9 *$ & 1.1 & 0.2 & 32.7 & 17.9 & 0.0 \\
\hline 10. & E $38 \times$ E 58 & $-4.4 * *$ & -3.0 & -2.4 & 0.5 & 0.3 & 4.8 & 43.0 & 1.0 \\
\hline 11. & Е $38 \times$ E 63 & $-3.4 * *$ & 12.4 & 0.3 & 0.4 & 0.3 & 22.1 & 33.4 & 0.2 \\
\hline 12. & Е $38 \times$ E 64 & $-1.5^{*}$ & 7.2 & 6.8 & 0.4 & $0.4^{*}$ & 46.9 & 6.1 & 0.3 \\
\hline 13. & E $38 \times$ E 79 & $-1.6 *$ & 7.2 & -3.1 & $2.0 *$ & $0.6 * *$ & $57.5^{*}$ & -42.3 & -0.3 \\
\hline 14. & E $40 \times$ E 58 & -0.1 & 11.8 & 4.3 & -0.3 & 0.0 & 10.2 & -6.1 & -0.5 \\
\hline 15. & E $40 \times$ E 61 & 1.1 & $18.9 *$ & 16.5 & -0.1 & 0.1 & -4.4 & 27.1 & 0.4 \\
\hline 16. & E $40 \times$ E 63 & 0.1 & $17.1^{*}$ & $11.0^{*}$ & 1.0 & -0.2 & -24.3 & -2.3 & 0.6 \\
\hline 17. & E $40 \times$ E 64 & $-4.4 * *$ & 5.1 & 4.5 & 0.2 & 0.3 & -11.4 & -38.9 & -0.2 \\
\hline 18. & E $40 \times$ E 79 & 0.3 & -4.5 & -7.2 & 0.0 & $0.4^{*}$ & & 39.3 & -0.8 \\
\hline 19. & E $58 \times$ E 61 & $-1.3 *$ & 5.7 & 3.3 & -0.1 & 0.1 & 19.9 & 16.8 & 0.2 \\
\hline 20. & Е $58 \times$ E 63 & $-1.9 *$ & $-27.8 * *$ & -2.9 & 0.1 & 0.3 & 38.5 & 28.4 & 0.7 \\
\hline 21 & E $58 \times$ E 64 & $-2.7 * *$ & -0.3 & 1.5 & 0.6 & 0.1 & 26.5 & -3.4 & 0.5 \\
\hline 22. & Е $58 \times$ E 79 & $-3.4 * *$ & 9.8 & -1.1 & 1.1 & 0.3 & 44.4 & 16.6 & $1.4^{*}$ \\
\hline 23. & E $61 \times$ E 63 & $-2.2 *$ & -4.9 & $-10.8 *$ & -0.4 & -0.1 & 7.9 & $106.3 * *$ & 0.3 \\
\hline 24. & E $61 \times$ E 64 & $1.4^{*}$ & -10.5 & -5.8 & 0.7 & 0.0 & 43.2 & -12.6 & 0.6 \\
\hline 25. & E $61 \times$ E 79 & $-3.7 * *$ & $19.4^{*}$ & 6.4 & 1.3 & $0.4^{*}$ & 45.8 & -48.5 & 0.2 \\
\hline 26. & E $63 \times$ E 64 & $2.4 * *$ & -0.4 & -5.4 & 0.7 & -0.2 & 8.5 & -15.5 & -0.8 \\
\hline 27. & E $63 \times$ E 79 & $-2.6 * *$ & $23.7 * *$ & 4.6 & 1.6 & 0.3 & 29.4 & 6.7 & $2.2 * *$ \\
\hline \multirow[t]{4}{*}{28.} & E $64 \times$ E 79 & $-2.4 * *$ & 8.3 & 5.4 & $1.7 *$ & $-0.4^{*}$ & 54.7 & 32.8 & $1.4^{*}$ \\
\hline & SE(ij) & 0.78 & 7.20 & 4.84 & 0.80 & 0.18 & 27.72 & 37.73 & 0.55 \\
\hline & LSD (5\%) & 1.60 & 14.75 & 9.91 & 1.64 & 0.37 & 56.77 & 77.27 & 1.13 \\
\hline & LSD (1\%) & 2.16 & 19.89 & 13.37 & 2.21 & 0.50 & 76.59 & 104.25 & 1.52 \\
\hline
\end{tabular}

$*$, ** indicated at $5 \%$ and $1 \%$ level of significance 


\section{Specific combining ability (sca) effects}

The specific combining ability effects of the crosses are presented in Table 4 . For days to silking, significant negative sca effect was observed in 18 crosses. Significant negative sca effects for plant and ear height were observed in one cross for each of these traits. The yield components viz., ear length, ear diameter, kernels per ear, and kernel weight exhibited significant sca effects in five, six, four, and one combinations respectively. These are identified as the best combinations, exhibiting significant positive sca effects for these characters (Table 4).

Out of 28 crosses, seven showed significant positive sca effects for yield. In most of the cases, one or both the parents were related to good combiners, indicating the GCA of the parental lines playing a key role for high yield. Xingming et al. (2002) drew similar conclusion. Most of these high sca crosses also possessed high per se performances (Table 1). Vasal (1998) suggested to include one good combiner (especially female parent) during crossing to obtain higher heterosis. This confirmed the present results. Williams (1959) also explained that a superior parent for one component should be crossed with a parent superior for another to obtain heterosis for a complex trait like yield. Vasal (1998) also suggested that both combining ability and per se performance are important, and thus balanced resources must be spent on each of these two aspects. The highest values of sca effects for kernel yield was observed in E63×E79 (2.2) followed by that in E-31× E-64 (2.1) and E-31× E-79 (1.9). The desirable significant sca effects observed for different characters were exhibited by the crosses involved high $\times$ high, high $\times$ average, average $\times$ average or high $\times$ low and low $\times$ low general combining parents. High sca effects manifested by different crosses of good combining parents might be attributed to sizeable additivexadditive gene action. The high $\times$ low combinations, besides expressing the favourable additive effect of the high parent, manifested some complementary gene interaction effects with a higher sca. An appreciable amount of the sca effects expressed by low $\times$ low crosses might be ascribed to dominance $\times$ dominance type of non-allelic gene action produced over dominance and are non-fixable. It appears that superior performances of the most hybrids might be largely due to epistatic interaction. The sca effects of the crosses exhibited no specific trends in cross combinations between parents having high, medium and low gca effects. Any combination among the parents may produce hybrid vigour over the parents which might be due to dominant, over dominant or epistatic gene action. So, the crosses showing desirable sca effects can be used in future hybrid breeding programs. 


\section{Conclusion}

The crosses E 31× E 40, E 31× E 64, E 31× E 79, E 38× E 40, E 58× E 79, E $63 \times$ E 79, and E $64 \times$ E 79 showing significant and positive sca effects could be used for commercial hybrid variety development after verifying at different locations.

\section{References}

Das, U.R. and M. H. Islam. 1993. Genetics of kernel weight in maize (Zea inays L.). Bangladesh J. P1. Breed. Genet. 6 (2): 53-57.

Debnath, S.C. and K.R. Sarker. 1989. Variance components analysis of six quantitative characters in maize. Bangladesh J. Pl. Breed. Genet. 2: 13-17.

Debnath, S.C. and K.R. Sarker. 1990. Combining ability analysis of grain yield and some of its attributes in maize (Zea mays L.). Indian J. Genet. 50: 57-61.

Derera, J., P. Tongoona, B.S. Vivek and M.D. Laing. 2007. Gene action controlling grain yield and secondary traits in southern African maize hybrids under drought and nondrought environments. Euphytica 162:411-422.

Dhillon, B. S. and J. Singh. 1976, Diallel analysis of yield and other traits of maize varieties. SABRAO J. 8: 147-152.

Drew, M.C., M.B. Jackson and S. Giffard. 1979. Ethylene promoted adventitious rooting and development of cortical air spaces (arenchyma) in roots may be adaptive response to flooding in Zea mays L. Planta 174: 83-88.

Fausey, N.R., T.T. Vantoai and M.B. MnDonald. 1985. Response of ten corn cultivars to flooding. Trans ASAE. 28: 1794-1797

Griffing, B. 1956. Concept of general and specific combining ability in relation to diallel crossing system. Aus. J. Bio. Sci. 9: 463-493.

Hussain, S.A., M. Amiruzzaman and Z. Hossain. 2003. Combining ability estimates in maize. Bangladesh. J. Agril. Res. 28: 435-440.

Moll, R. H. and C.W. Stuber. 1974. Quantitative genetics empirical results relevant to plant breeding. Ad. Agron. J. 26: 277-313.

Murthy, A.R., N.B. Kajjari and J.V Goud. 1981. Diallel analysis of yield and maturity components in maize. Indian J. Genet. and Plant Breeding 41: 30-33.

Paul, S.K. and P.K. Duara. 1991, Combining ability for yield and maturity in maize (Zea mays L.). International J. Tropical Agric. 9(4): 205-254.

Rathore, T.R., M.Z.K. Warsi, P.H. Zaidi and N.N. Singh. 1997. Water logging problem for maize production in Asian region. TAMNET News Letter 4: 13-14.

Singh, S. N., K. N. Singh and H.G. Sinch. 1983. Combining ability studies in maize. Crop Improv. 10(1): 6-9. 
Torbert, H.A., R.G. Hoeft, R.M.V. Heuvel, R.L. Mulvancy and S.E. Hollonger. 1993. Short term excess water impact on corn yield and nitrogen recovery. J. Prod Agril. 6: 337-344.

Vasal, S.K. 1998. Hybrid maize technology: Challenges and expanding possibilities for research in the next century. In: Vasal, S.K., C.F. Gonzalez and F. Xingming (eds). Proc. 7th Asian Reg. Maize Workshop. Los Banos, Philippines, February 23-27, Pp. 58-62.

Williams, W. 1959. Heterosis and genetics of complex characters. Nature 184: 527-530.

Xingming, F., J. Tan, Z. Chen, and J. Yang. 2002. Combining ability and heterotic grouping of ten temperate, tropical and subtropical quality protein maize. In: Srinivasan, G., P.H. Zaidi, B.N. Prasanna, F.C. Gonzalez and K. Lesnick (ed). Proc. 8th Asian Reg. Maize Workshop. Bangkok, Thailand, August 5-8. Pp. 10-18. 